RESEARCH PAPER

J. Food Sci. Technol. Nepal, Vol. 8 (65-70 ) 2013

ISSN: 1816-0727

\title{
Optimization of Cultural Conditions for the Production of Pectinase from Selected Fungal Strain
}

\author{
RAJIV DHITAL ${ }^{1}$, OM PRAKASH PANTA ${ }^{1}$ and TIKA BAHADUR KARKI ${ }^{2}$ \\ ${ }^{1}$ Department of Microbiology, National College, Khusibu, Nepal \\ ${ }^{2}$ Department of Biotechnology, Kathmandu University, Dhulikhel, Nepal
}

*Corresponding author: dhitalrajiv@hotmail.com

Pectinase are the group of enzymes that catalyze the degradation of pectin substances through de-polymerisation and de-esterification. This study is concerned on the isolation, screening and selection of suitable strain of pectinolytic organism and optimization of cultural conditions for the biosynthesis of pectinase. From the soil samples collected from Lalitpur, Kathmandu, Gulmi, Manang and Dang, 18 fungal colonies were isolated on the basis of halozone formation on Potato dextrose agar and identified. Enzyme production was carried out by submerged state fermentation. The partially purified enzymes showing higher pectinolytic activity were characterized on the basis of temperature of incubation, substrate concentration and $\mathrm{pH}$ of the substrate by Dinitro salicylic acid assay (DNSA) method. The fungal isolate showing highest enzyme activity was subjected to optimization of culture medium for the production of enzymes. On optimization, it was found that $M G_{1}$ (Aspergillus niger) was the most potent strain at $1.5 \%$ substrate (pectin) concentration, $\mathrm{pH} 4.5$ and temperature of $30^{\circ} \mathrm{C}$. On the enzyme application, the yield of the orange juice, Total Soluble Solid and absorbance increased as the concentration of the enzyme increased and hence increasing the possibility of being used commercially for maximum pectinase production.

Keywords: Pectinase, optimization, substrate concentration, $\mathrm{pH}$, temperature, $\mathrm{MG}_{1}$

\section{Introduction}

Pectin is an important component of middle lamella and primary cell wall of higher plants. These arehigh molecular weight acid polysaccharide primary made up of $\alpha(1-4)$ linkage of D-galacturonic acid residues (Patil et al., 2010). Pectic substances are glycosidic macromolecules with high molecular weight. These substances consist of protopectins, pectinic acids, pectins and pectic acids. The main chain of pectin is partially methyl esterified 1,4-D-galacturonan. Demethylated pectin is known as pectic acid (pectate) or polygalacturonic acid. Three major pectic polysaccharide group are recognized, all containing D-galacturonic acid to a greater or a lesser extent. They are homogalacturonan (HG), rhamnogalacturonan I (RGI), and rhamnogalacturonan II (RGII). Similarly, American Chemical Society has classified pectic substances into four main types as protopectin, pectic acid, pectinic acid and pectin (Polymethylgalacturonate) (Singh et al., 2005).

Pectinases are commercially important enzymes belonging to group hydrolase. Pectinase enzyme hydrolyzes the pectin present in plant cell wall and the middle lamella and play a vital role in physiological process that take place in plant like cell wall extension, fruit ripening, softening of plant tissues during maturation
etc.(Sakai ,1993). Pectinases have wide applications in food industries. The applications include clarification of wine and juice, scouring of cotton, degumming of plant fibers, waste water treatment, vegetable oil extraction, tea and coffee fermentations, bleaching of paper, and in poultry feed additives (Rangarajan et al., 2010).

Pectinolytic enzymes have been reported from different genera of bacteria, including actinomycetes, yeast, and fungi. Pectinases from Erwinia, Bacillus, Saccharomyces, Kluyveromyces, Aspergillus, Penicillium, Fusarium and Rhizopus have been isolated and characterized.Most of the commercial preparations of pectinases are produced from fungal sources viz Aspergillus, Erwinia and Penicillium (Khairnar et al., 2009), however, Aspergillus niger is the major source of commercially important pectinase (Rangarajan et al., 2010).

Pectic substance is a generic name used for the compounds that are acted upon by the pectinolytic enzymes. These are negatively charged acidic glycosidic macromolecules and have high molecular weight (Patil and Dayanand, 2006). Microbial pectinases account for $25 \%$ of the global industrial enzymes among overall pectinase production (Jayani et al., 2005). 
There are multitudes of food and beverage industries in Nepal which require pectinase enzyme during various processing steps. Keeping in view the importance of enzyme pectinases in the food processing industry and the problems associated with the disposal of waste from food processing industry, the present study was undertaken with the purpose of isolation and screening of pectinase producing micro-organism. Simultaneously, optimization of different conditions for the production, extraction and purification of this enzyme will overcome the acute demand of this enzyme.

\section{Materials and Methods \\ Sample}

From different areas of Lalitpur, Kathmandu, Gulmi, Manang and Dang, soil sample was collected from the areas where soil was rich in composts, agro-industrial wastes and organic fertilizers.

\section{Isolation, screening and identification of pectinolytic} fungi

Potato Dextrose Agar (PDA) enriched with $1 \%$ pectin was used. Isolation of fungi was done by soil dilution plate method and incubated at $25^{\circ} \mathrm{C}$ for 7 days. Different colonies were selected and duplicated. Then 1\% Cetyl Trimethyl Ammonium Bromide (CTAB) was flooded on one of the plate and incubated at $26^{\circ} \mathrm{C}$ for an hour. Pectinolytic fungi were indicated by the zone of hydrolysis around the colonies and the zone of hydrolysis was measured. Similarly, secondary screening was done by measuring the diameter of halozone formed by the fungal isolates in PDA enriched with $1 \%$ pectin. Identification was done on the basis of cultural and morphological characteristics by Lactophenol Cotton Blue staining method (Aneja, 2008). The stock cultures of isolated colonies were maintained on PDA slant and preserved at $4^{\circ} \mathrm{C}$.

\section{Enzyme production}

Submerged state fermentation was carried out using $50 \mathrm{ml}$ Hankin's broth was prepared and autoclaved. After sterilization, $1 \mathrm{ml}$ of each pre-fermenter inoculum was inoculated. The flasks were shaken at $150 \mathrm{rpm}$ and incubated at $30^{\circ} \mathrm{C}$ for 7 days and fermentation was monitored for PG activity using Dinitro Salicylic Acid Assay (DNSA) and cup plate method.

\section{Extraction and partial purification of enzyme produced:} After 7 days of fermentation, the fungal cultures were separated from crude enzyme by filtration using Whatmann No.1 filter paper. The filtered enzymes were then were partially purified by acetone precipitation.

\section{Characterizations of partially purified pectinases}

The partially purified enzymes obtained after the precipitation with acetone showing highest PG activities were subjected to different enzymatic parameters for identifying their optimal working ranges. The effects of different parameters like $\mathrm{pH}$, temperature and substrate concentration were studied.

\section{Optimization of cultural conditions for pectinase} production

The fungal strains showing high pectinase production and high pectinolytic activity were selected. The optimum growth characteristics of the fungal strains for the yield of pectinase were studied. The effects of $\mathrm{pH}$, substrate concentration and temperature of incubation on production of pectinase were studied.

\section{Effect of $p H$ on pectinase production} To study the effect of $\mathrm{pH}$ on pectinase production, Yeast Glucose Pectin (YGP) media $(1000 \mathrm{ml})$ with varying $\mathrm{pH}$ of $2.5,3.5,4.5$, and 5.5 were made, autoclaved and cooled. Then $0.5 \mathrm{ml}$ of spore inoculum was inoculated in each media. These media were then incubated at $30^{\circ} \mathrm{C}$ for 2 days. After incubation the enzyme assay was carried out by DNS assay method (Miller, 1959).

\section{Effect of temperature on pectinase production} To study the effect of temperature on pectinase production, $100 \mathrm{ml}$ of Yeast Glucose Pectin (YGP) media was prepared, autoclaved and cooled. Then the $0.5 \mathrm{ml}$ of spore inoculums was added and the flasks were incubated separately at $20^{\circ} \mathrm{C}, 30^{\circ} \mathrm{C}, 40^{\circ} \mathrm{C}, 50^{\circ} \mathrm{C}$ and $60^{\circ} \mathrm{C}$ for 2 days. After incubation, the enzyme assay was done by usual DNS assay method (Miller, 1959).

\section{Effect of substrate (pectin) concentration on pectinase production}

For the study of effect substrate concentration on pectinase production, YGP $(100 \mathrm{ml})$ media with pectin concentrations of $0.1 \%, 0.5 \%, 1.0 \%, 1.5 \%$, and $2.0 \%$ were prepared, autoclaved and cooled. Then about $0.5 \mathrm{ml}$ of spore inoculums was added to each substrate containing YGP media and incubated at $30^{\circ} \mathrm{C}$ for 2 days. After incubation enzymatic assay was performed by usual DNS method (Miller, 1959).

\section{Purification of enzyme}

The partially purified enzyme produced from the fungal sample was subjected to dialysis for further purification. The enzyme sample suspended in acetate buffer was placed in a sterile dialysis bag and placed in a beaker containing distilled water. The beaker containing the dialysis bag was kept in a magnetic stirrer for 24 hours. Finally, the purified enzyme in the dialysis bag was 
poured into a sterile test tube and suspended in acetate buffer of $\mathrm{pH} 4.2$.

\section{Application of enzyme \\ Extraction of orange juice and enzyme treatment}

Mature ripened orange fruits (Citrus sinensis) were sorted, washed and peeled. The juice was extracted using a domestic juice extractor. The extracted juice was pasteurized at $85^{\circ} \mathrm{C}$ for 3 minutes to inactivate the natural fruit enzymes and cooled down to $4^{\circ} \mathrm{C}$. Varying concentration of enzyme $(0,0.25,0.5,0.75$ and $1 \%)$ was added. The samples were incubated at $40^{\circ} \mathrm{C}$ for $1 \mathrm{hr}$. After incubation, the samples were heated at $85^{\circ} \mathrm{C}$ for 3 minutes to inactivate the enzyme.

\section{Determination of Yield, Total Soluble Sugar and Clarity of juice}

The clarified juice was filtered using Whatman No. 1 filter paper. The volume of fruit juice obtained was measured using $100 \mathrm{ml}$ measuring cylinder. The TSS was determined using refractometer. For clarity, the juice was shaken and $10 \mathrm{ml}$ portion of juice was centrifuged at 5000rpm for $10 \mathrm{~min}$ to remove pulp and coarse cloud particles. Percent transmittance and absorbance was determined at $560 \mathrm{~nm}$ by spectrophotometer.

\section{Data Analysis}

The data were analysed using SPSS computer program (version 17.0). Analysis of Variance (ANOVA) in one way classification system was used in the study for testing the statistical significance of variation of mean at $5 \%$ level. The Least Significant Difference (LSD) was used to compare the significance difference between the different parameters at $5 \%$ level.

\section{Results and Discussion}

The study was carried out to isolate and screen pectinolytic organisms from environmental soil sample from different parts of Nepal for the production of valuable product pectinase. A total of 9 different soil samples [Lalitpur (3), Kathmandu (2), Gulmi (2), Manang (1) and Dang (1)] were collected and analyzed for the growth of fungal colonies. From those, 40 different colonies were screened primarily on the basis of hydrolysis around the colonies. Among them only 18 colonies were selected for enzyme production by secondary screening using PDA enriched with pectin. From microscopy and cultural characteristics, 14 strains were identified as genus Aspergillus whereas remaining four were found to be Fusarium, Penicillium, Rhizopus ans Syncephalastium. Submerged state fermentation was carried out for 7 days and analysis of crude enzymes produced by these 18 fungal isolates was done routinely at
24 hours interval for 5 days. The enzymes were partially purified by filtration followed by acetone precipitation. Out of 18 enzyme sample produced from 18 different fungal isolates, 3 enzyme samples produced from three isolates namely $\mathrm{MG}_{1}, \mathrm{MM}_{1}$ and $\mathrm{TC}_{5}\left(\mathrm{~B}_{1}\right)$ were selected for enzyme characterization. The activities of these three enzymes were characterized on the basis of three factors namely; temperature of incubation, substrate (pectin) concentration and $\mathrm{pH}$ of the substrate.

Table 1. Assay of enzymes at different temperatures

\begin{tabular}{|c|c|c|c|c|}
\hline \multirow{2}{*}{$\begin{array}{l}\text { Enzy me } \\
\text { Samples }\end{array}$} & \multicolumn{4}{|c|}{ OD at 540nm at different temperatures } \\
\hline & $25^{\circ} \mathrm{C}$ & $37^{\circ} \mathrm{C}$ & $45^{\circ} \mathrm{C}$ & $55^{\circ} \mathrm{C}$ \\
\hline $\mathrm{MM}_{1}$ & 0.04 & 0.06 & 0.10 & 0.13 \\
\hline $\mathrm{MG}_{1}$ & 0.04 & 0.07 & 0.20 & 0.16 \\
\hline $\mathrm{TC}_{5}\left(\mathrm{~B}_{1}\right)$ & 0.06 & 0.06 & 0.16 & 0.14 \\
\hline
\end{tabular}

Table 2. Assay of enzymes at various substrate concentrations

Enzyme OD at 540nm at various substrate concentrations

\begin{tabular}{lcccccc} 
Samples & $\mathbf{0 . 3 \%}$ & $\mathbf{0 . 5 \%}$ & $\mathbf{1 \%}$ & $\mathbf{1 . 5 \%}$ & $\mathbf{2 . 0 \%}$ & $\mathbf{2 . 5 \%}$ \\
\hline $\mathrm{MM}_{1}$ & 0.10 & 0.01 & 0.02 & 0.02 & 0.04 & 0.04 \\
$\mathrm{MG}_{1}$ & 0.14 & 0.01 & 0.01 & 0.02 & 0.06 & 0.06 \\
$\mathrm{TC}_{5}\left(\mathrm{~B}_{1}\right)$ & 0.11 & 0.02 & 0.02 & 0.01 & 0.06 & 0.06 \\
\hline
\end{tabular}

Table 3. Assay of enzymes at various pH of substrates

\begin{tabular}{lcrc}
\hline $\begin{array}{l}\text { Enzyme } \\
\text { Samples }\end{array}$ & \multicolumn{4}{c}{ OD at 540nm at various pH of substrate } \\
\hline $\mathrm{MM}_{1}$ & 0.09 & 0.09 & 0.10 \\
$\mathrm{MG}_{1}$ & 0.08 & 0.11 & 0.12 \\
$\mathrm{TC}_{5}\left(\mathrm{~B}_{1}\right)$ & 0.11 & 0.11 & 0.11 \\
\hline
\end{tabular}

From the three enzyme samples, enzyme sample $\mathrm{MG}_{1}$ exhibited higher pectinolytic activity as compared to other two samples. It showed whitish margin with brownish black with conidial production and reverse was white to pale yellow on PDA. The growth characteristic of the fungi on PDA after 7 days of incubation revealed that colonies on PDA at $28^{\circ} \mathrm{C}$ were initially white and became greenish black with conidial production. Reverse was white to pale yellow and with growth produced in the agar. The microscopic result showed large, globular spore bearing heads and were tightly packed. Chains of conidia were also seen. The conidia were greenish in color. The feature resembled that of Aspergillus niger.

For the production of pectinase in optimum cultural condition the fungus was grown on Yeast Glucose media. Factors such as substrate concentration, $\mathrm{pH}$ of the substrate media and temperature were varied to analyze the optimum enzyme production by the fungus. The 
maximum enzyme production was observed on the YGP media enriched with pectin at the concentration of $1.5 \%$ which was $21 \mathrm{U} / \mathrm{ml}$ (Figure 1). Similarly, maximum pectinase production i.e. $7 \mathrm{U} / \mathrm{ml}$ was observed at $\mathrm{pH} 4.5$ of YGP media (Figure 2). The optimum temperature for maximum enzyme production was found to be at $30^{\circ} \mathrm{C}$. At this temperature, $32 \mathrm{U} / \mathrm{ml}$ enzyme was produced (Figure 3).The enzyme activity was found to be significantly related with substrate concentration, $\mathrm{pH}$ and temperature of incubation $(\mathrm{p}<0.05)$.

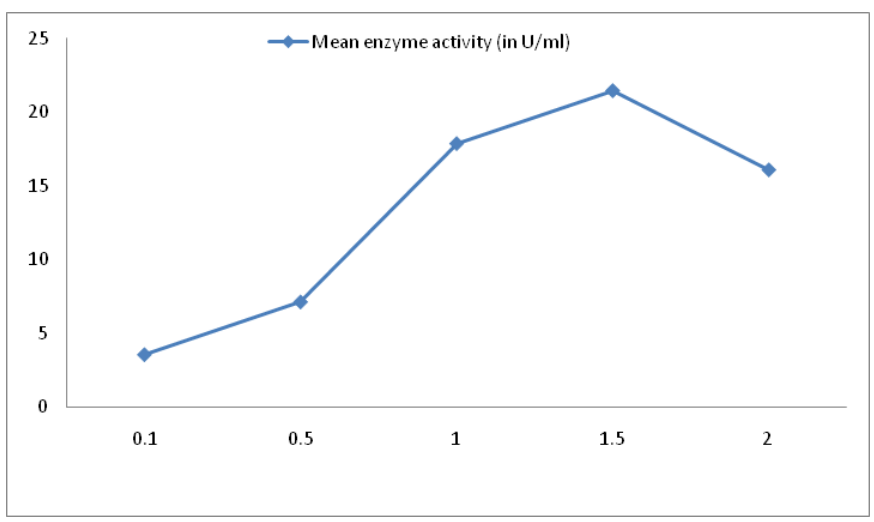

Figure 1. Effect of substrate concentration on pectinase production (Strain $\mathbf{M G}_{1}$ )

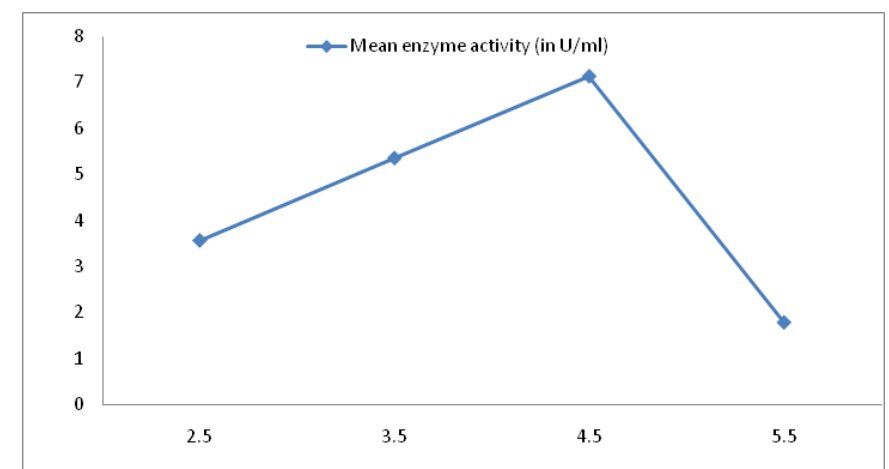

Figure 2. Effect of $\mathrm{pH}$ on pectinase production (Strain MG)

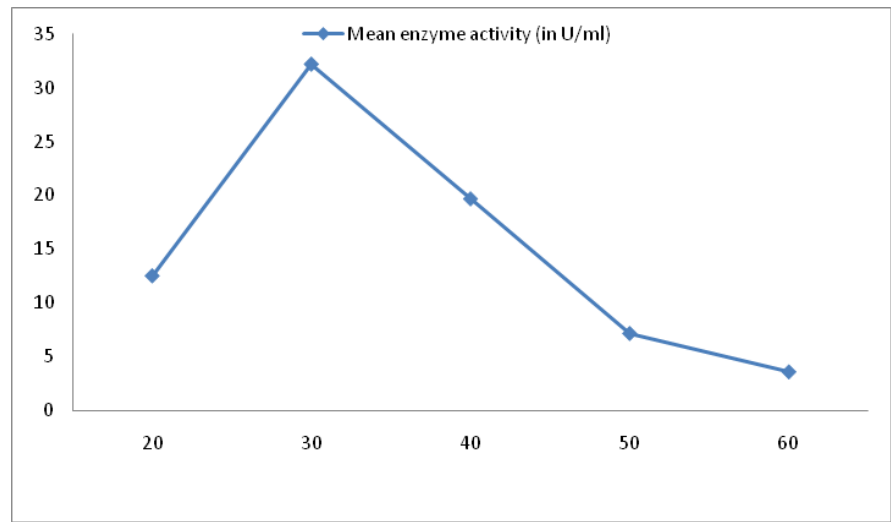

Figure 3. Effect of temperature on pectinase production (Strain MG M $_{1}$
The yield of the orange juice and TSS increased as the concentration of the enzyme increased. Highest activity was observed in the enzyme concentration $1 \%$, absorbance 0.75 at $540 \mathrm{~nm}$ and enzyme activity of 20.9407 U/ml (Table 4).

Table 4. Effect of different pectinase concentrations on yield and total soluble solids

\begin{tabular}{|c|c|c|c|c|c|}
\hline \multirow{2}{*}{$\begin{array}{c}\text { Enzyme } \\
\text { concentration } \\
(\%)\end{array}$} & \multicolumn{2}{|c|}{ Yield } & \multicolumn{2}{|c|}{$\begin{array}{l}\text { Total Soluble } \\
\text { Solids (TSS) }\end{array}$} & \multirow[t]{2}{*}{$\begin{array}{c}\text { Absorbance } \\
\text { at } 540 \mathrm{~nm}\end{array}$} \\
\hline & $\begin{array}{c}\text { Initial } \\
\text { volume(ml) }\end{array}$ & $\begin{array}{c}\text { Final } \\
\text { volume }(\mathrm{ml})\end{array}$ & $\begin{array}{l}\text { Initial } \\
\left({ }^{\circ} \text { Brix }\right)\end{array}$ & $\begin{array}{l}\text { Final } \\
\left({ }^{\circ} \text { Brix }\right)\end{array}$ & \\
\hline 0 & 20 & 20 & 6 & 6 & 0 \\
\hline 0.25 & 20 & 20.2 & 5 & 5.5 & 0.48 \\
\hline 0.5 & 20 & 20.5 & 5 & 5.5 & 0.66 \\
\hline 0.75 & 20 & 21.0 & 5 & 6 & 0.70 \\
\hline 1 & 20 & 21.7 & 5 & 7 & 0.75 \\
\hline
\end{tabular}

The present study revealed that all the 18 isolates have shown extracellular enzyme activity. Among the 18 fungal colonies assayed for the extracellular enzyme activity, majority of the fugal culture showed that the pectinase activity was decreasing after 48 hours of incubation. It might be due to the depletion of the nutrients, death phase of organisms or due to the production of pectinase in the medium as suggested by the previous report. The Aspergillus niger strain showed maximum activity after 24 hours of incubation and later on the activity started depleting when the incubation time was increased (Khairnar et al., 2009). Three fungal strains namely $\mathrm{MM}_{1}, \mathrm{MG}_{1}$ and $\mathrm{TC}_{5}(\mathrm{~B})$ were selected on the basis of maximum diameter of halozone formation on the media enriched with pectin. These three fungal strains were selected for further study. The isolated fungal strains were characterized on the basis of pectinase production using three parameters i.e. temperature, $\mathrm{pH}$ and substrate concentrations. The enzyme produced by these three isolates were assayed varying the temperature of incubation $\left(25-55^{\circ} \mathrm{C}\right)$, the substrate concentrations $(0.3 \%-2.5 \%)$, and varying the $\mathrm{pH}$ of the substrate (3.65.2). The enzyme activity was found to increase within temperature range of $45^{\circ} \mathrm{C}-55^{\circ} \mathrm{C}$. The enzyme showed highest activity at temperature of $55^{\circ} \mathrm{C}$ which indicates the pectinolytic enzymes are active at high temperatures. But, the activity of enzymes decreases when temperature is further increased. In a similar research on pectinase, the activity of enzyme activity remained stable up to $70^{\circ} \mathrm{C}$. The assay of the three enzymes using various concentrations of substrate showed that the enzyme activity increased up to $2 \%$ substrate concentration and then remained stationary on increasing the substrate concentration. This may be due to fact that at high substrate concentration 
no more enzymes are available free for carrying the reaction (or catalysis) since the enzyme is constant. The partially purified enzymes were assayed for the activity in varying $\mathrm{pH}$ condition of the substrate media. Maximum pectinase production was observed at $\mathrm{pH} 5.2$, which indicates that slightly acidic condition is suitable for the production of pectinase. It has been reported that the exopolygalacturonase and endopolygalacturonase obtained from Aspergillus niger URM4645 showed its maximum activity at $\mathrm{pH} 7.0$ and 5.0 respectively (De Holanda Cavalcanti Macial et al., 2011). Fahmy et al., (2008) found that the pectinase isolated from Aspergillus niger has optimum activity at $\mathrm{pH}$ 5.0. Among the enzyme produced from the various fungal strains, $\mathrm{MG}_{1}$ showed higher pectinolytic activity as compared to other two isolates. Three different parameters namely substrate concentration, $\mathrm{pH}$ of the substrate and temperature of incubation were taken for optimization. The media cultures were tested for pectinase production for two days. The fungus inoculated into the YGP media with different concentrations of substrate showed that $21 \mathrm{U} / \mathrm{ml}$ enzyme was produced at $1.5 \%$ substrate concentration. The maximum yield of pectinase was obtained at pectin concentration of $1.5 \%$ by Penicillium spp (Patil and Chaudhari, 2009).Similarly, by doing the assay of the fungus inoculated into YGP media of different $\mathrm{pH}$ showed maximum pectinase production at $\mathrm{pH} 4.5$ shown in figure 4.2. I.e. $7 \mathrm{U} / \mathrm{ml}$ enzyme was produced. It was also found that maximum production of pectinase from Aspergillus niger and Aspergillus awamori was observed at pH 5.0 (Suresh et al., 2009; Suresh and Viruthagiri, 2010). These findings are very close to our results which indicate that the result obtained must be true for the pectinase production from Aspergillus spp. The optimum temperature for the enzyme production was found to be at $30^{\circ} \mathrm{C}$ as shown in figure 4.3 , i.e. $32 \mathrm{U} / \mathrm{ml}$ enzyme was produced at $30^{\circ} \mathrm{C}$. So, the maximum enzyme production was observed at normal temperature $\left(30^{\circ} \mathrm{C}\right)$ at which majority of fungi are found to grow. The On the enzyme application, the yield of the orange juice, TSS and absorbance increased as the concentration of the enzyme increased. The result of ${ }^{\circ}$ Brix analysis on enzyme treated orange juice indicated a slight increase in soluble solids in enzyme concentration of 1\%. Earlier studies have also revealed a similar kind of result where they changed from 6.0 to 6.2 and 8.6 to 11.20

\section{Conclusions}

The demand of industrially important enzymes in food industries is rising enormously. So, research should be done to alleviate the demand of these enzymes. Pectin degrading enzyme like pectinase has received a great attention because of their wide application and economic benefits. On the other hand the production of pectinases for industrial application can be achieved by growing the potent organisms in a cheap substrate. The fungal isolate $\mathrm{MG}_{1}$ could be potential candidate for industrial production of pectinase. It is thought that more efficient strains with enzymes with required quality could be isolated if the search for such organisms is carried out over different ecological regions of Nepal. In addition more specific and quality research work as well as development of gene cloning technique to produce the enzymes in large scale so as to meet industrial demands.

\section{References}

Aneja KR (2008). Experiments in Microbiology, Plant pathology and Biotechnology, $4^{\text {th }}$ edn. New Age International $(\mathrm{P})$ limited publishers, Ansari Road, Daryagunj, New Delhi.

De HolandaCavaalcantiMaciel M, Herculano PN, Porto TS, Teixeira MFS, Moreira KP and de Souza-Motta CM (2011) production and partial characterization of pectinase from forage palm by Aspergillusniger URM4645. Afr J of Biotechnol. 10 (13): 2469-2475.

Jayani RS, Saxena S and Gupta R (2005) Microbial pectinolytic enzymes: A review. Process Biochem.40:2931-2944.

Khairnar Y, Vamsi KK, BorasteA , Gupta N, Trivedi S, Patil P, Gupta G, Gupta M, Jhadav A, Mujapara A, Joshi B., Mishra D (2009). Study of pectinase production in submerged fermentation using different strains of Aspergillusniger. Int. J. Microbiol. Res.1 (2):13-17.

Miller LG (1959) Use of dinitrosalicylic acid reagent for the determination of reducing sugar. Anal Chem.31:426-473.

Patil SR and DayanandA (2006) Optimization of process for the production of fungal pectinases from deseeded sunflower head in submerged and solidstate conditions. Biosource Technol.97: 2340-2344.

Patil NP and Chaudhari BL (2009) Production and Purification of pectinase by soil isolate Penicillium sp and search for better agro-residue for its SSF. Recent Research Sci Technol. 2(7): 36-42

Patil, N. P. and Chaudhari, B. L. (2010) Production and purification of pectinase by soil isolate Penicillumspp and search for better agro-residue for its SSF. Recent Research in Science and Technology 2010, 2(7): 3642.

Rangarajan V, Rajasekharan M, Ravichandran R, Sriganesh K and Vaitheeswaran R (2010) Pectinase production from orange peel extract and dried orange peel solid substrates using Aspergillusniger. Int $J$ Biotechnol. Biochem. 6(3): 445-453. 
Dhital et al.: J. Food Sci. Technol. Nepal, Vol. 8 (65-70 ), 2013

Sakai T, Sakamoto T, Hallaert $\mathrm{J}$ and Vandamme EJ (1993) Pectin, pectinase and protopectinase: production, properties and applications. Adv Appl Microbiol.39:231-94

Singh J.R., Saxena S., Gupta R. (2005) Microbial pectinolytic enzymes: A review Process Biochemistry, 40: 2931-44.

Suresh B, Viruthagiri T and Sasikumar E (2009) Optimization of process variables using Response Surface Methodology (RSM) in the solid-state fermentative production of pectinase by Aspergillus awamori. Asian J Food Ag Ind. 2(3): 303-314. 